\title{
GMR
}

\section{Extraction of proteins and preliminary characterization of physicochemical properties in Toona sinensis fruit}

\author{
W.-Z. Li, W.-N. Han, B. Liu, S.-H. Ding, X.-K. Zhang and R.-S. Wang \\ College of Pharmacy, Weifang Medical University, Weifang, \\ People's Republic of China \\ Corresponding author: W.-Z. Li \\ E-mail: wanzhong_06@163.com
}

Genet. Mol. Res. 16 (1): gmr16019177

Received September 6, 2016

Accepted December 20, 2016

Published February 8, 2017

DOI http://dx.doi.org/10.4238/gmr16019177

Copyright $(92017$ The Authors. This is an open-access article distributed under the terms of the Creative Commons Attribution ShareAlike (CC BY-SA) 4.0 License.

\begin{abstract}
We investigated the extraction of Toona sinensis fruit proteins and preliminarily characterized their physicochemical properties. The results showed that optimal extraction occurred under conditions of $\mathrm{pH} 10.5$, a duration of $40 \mathrm{~min}$, a liquid-to-solid ratio of 25:1, and a temperature of $40^{\circ} \mathrm{C}$ by an orthogonal design using $T$. sinensis fruit protein as the index and single factor. The total nitrogen content was $13.8 \mathrm{~g} / 100 \mathrm{~g}$ and included 17 different amino acids. The glutamate level was highest at $35.37 \%$, followed by arginine at $15.31 \%$. The isoelectric point of $T$. sinensis fruit protein was between 6.8 and 10.0 with a typical absorption peak by infrared chromatography. Three protein bands were analyzed using SDS-polyacrylamide gel electrophoresis, with relative molecular weights of 55,51, and $22 \mathrm{kDa}$. This study provides a theoretical basis for the comprehensive utilization of $T$. sinensis fruit by further investigating the biological activity of its proteins.
\end{abstract}

Key words: Toona sinensis fruit; Extraction technology;

Total nitrogen content; Amino acids; Isoelectric point; SDS-PAGE

Genetics and Molecular Research 16 (1): gmr16019177 


\section{INTRODUCTION}

Toona sinensis fruit, a kind of Meliaceae, was recorded in "Materia Medica of the Tang Dynasty" (Xing and Chen, 2010), and is distributed widely in China. It is a medicine and food product, and its root, tree bark, bud, leaf, and fruit are usually used as medicine. As a traditional Chinese medicinal material, $T$. sinensis fruit is efficacious at dispelling wind and cold, analgesia, and is mainly used in the treatment of wind chill, exopathy, stomach ache, rheumatic joint pain, chest pain, anal fistula, chronic gastritis, headache, and migraine (Xing and Chen, 2010; He and Lin 2013).

The active components in $T$. sinensis fruit include phenols, tannins, alkaloids, saponins, steroids, terpenes, and volatile oil (Chen et al., 2000; Wang et al., 2006; Chen et al., 2008). The proteins from this plant possess specific physiological functions, which have attracted the attention of nutrilogical scientists. These proteins may reduce cholesterol levels (Higashi et al., 2001; Lee and Jung, 2002), prevent cancer (Rowlands et al., 2001), improve cardiovascular and kidney diseases (Jenkins et al., 2001; Appel, 2003), and support nutrition in patients with liver cirrhosis (Tang et al., 1996).

Few studies have been performed on T. sinensis fruit proteins, and the extraction technology used for health products, foods, and medicines was under the exploring stage in these fields. This study aimed to investigate the extraction of proteins from $T$. sinensis fruit, and to preliminarily characterize the physicochemical properties of these proteins. In order to comprehensively develop resources and investigate the nutrition and functional properties of these plant proteins, this study has important practical significance and broad market potential.

\section{MATERIAL AND METHODS}

\section{Equipment and reagents}

A Mettler Toledo electronic balance (EL204), European quality Household life grinder (DSY-9002), and thermostatic water container (HH600-2B) were obtained from Shanghai Binlon Instrument Co., Ltd. An air-blower-driven Drying Closet (101-1AB) was obtained from Tianjin Taisite Instrument Co., Ltd. An ultraviolet spectrophotometer (UV800A) was obtained from Shanghai Metash instruments Co., Ltd. The pH meter (pHS-3C) was obtained from Shanghai REX Instrument Factory. The automatic Kieltec Distilling system azotometer (K9860) was obtained from Jinan Hanon Instruments Co., Ltd. A HITACHI high speed AA analyzer (8900), and fourier transform infrared spectrometer (Vector22 FT-IR) were obtained from Bruker Corporation. A double-sided vertical electrophoresis tank (JY-SCZ2) was obtained from Beijing JUNYI Electrophoresis Co., Ltd., and the electrophoresis apparatus (DYY-6C) was obtained from Beijing LiuYi Instrument Factory.

T. sinensis fruit was brought from JiNan ShengKe Technology Development Co., Ltd. and identified as the fruit of T. sinensis (A. Juss.) Roem. by Dr. Xu from The Pharmacognosy Department of WeiFang Medical University. Coomassie brilliant blue G250 (Amresco 0615), an unstained protein molecular weight marker (Thermo Scientific), and standard reagents for analyzing amino acids (AAs) were obtained from Wako Pure Chemical Industries, Ltd.

\section{Extracting proteins from $T$. sinensis fruit}

T. sinensis fruits were ground, defatted in 95\% ethanol, and vacuum filtered. Distilled

Genetics and Molecular Research 16 (1): gmr16019177 
water was added to tubes containing appropriate filter residues, and the $\mathrm{pH}$ was adjusted to alkaline. The extraction process was conducted in a heated water bath. After centrifugation, the supernatant was discarded, and distilled water was added to adjust the $\mathrm{pH}$ to neutral. The precipitant was freeze-dried and the proteins were obtained.

\section{Measurement of protein contents}

Protein concentrations were measured as previously described (Wang et al., 2008).

\section{Preparation of test solution}

Bovine serum albumin (BSA) standard solution was prepared by dissolving $10.0 \mathrm{mg}$ BSA in distilled water with a constant volume of $100 \mathrm{~mL}$.

Coomassie brilliant blue G250 was prepared by dissolving $10 \mathrm{mg}$ Coomassie brilliant blue $\mathrm{G} 250$ in $90 \%$ ethanol $(5.0 \mathrm{~mL})$ with $85 \%(\mathrm{~W} / \mathrm{V})$ phosphoric acid $(10.0 \mathrm{~mL})$ and a constant volume of $100 \mathrm{~mL}$. Coomassie brilliant blue G250 was stored in a brown volumetric flask.

\section{Standard curve}

The BSA standard solutions $(0,0.1,0.2,0.3,0.4,0.5,0.6,0.7,0.8$, and $0.9 \mathrm{~mL})$ were added to separate tubes and distilled water was added to make each solution up to $1.0 \mathrm{~mL}$. Coomassie brilliant blue G250 (5 mL) was mixed and incubated for $5 \mathrm{~min}$. The absorbance was determined at $595 \mathrm{~nm}$. The standard curve was generated using concentrations of BSA standard solution $(\mathrm{mg} / \mathrm{mL})$ as the abscissa and the absorbance as the ordinate (Figure 1).

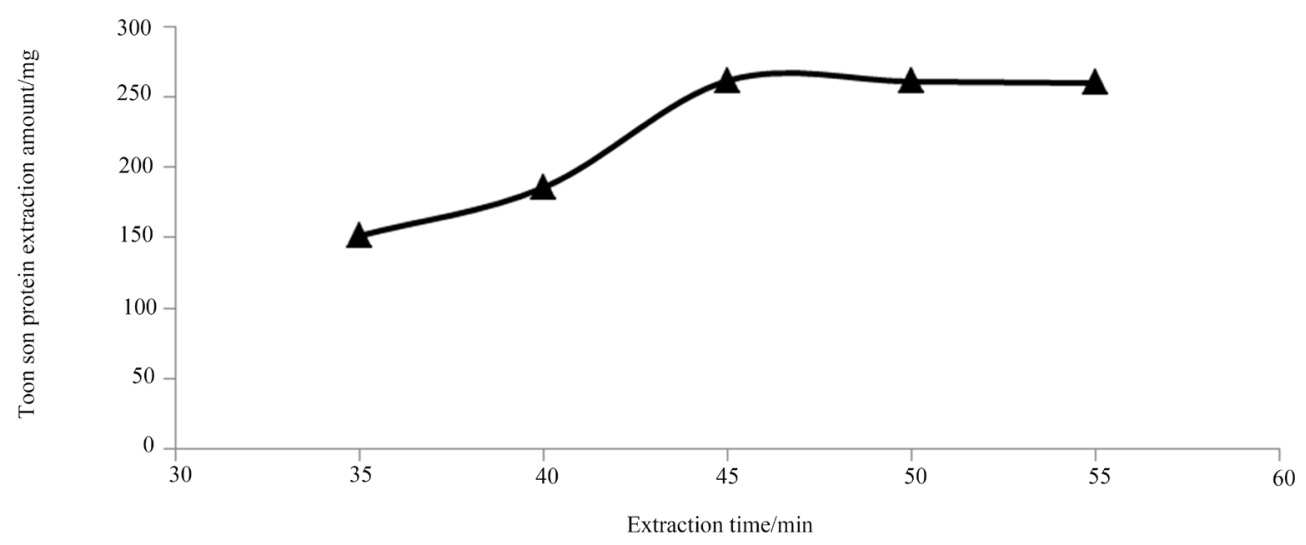

Figure 1. Effect of extraction time on extraction amount.

\section{Measurement of protein content}

The protein content in $T$. sinensis fruit was calculated by measuring the absorbance against the standard curve. Each experiment was repeated three times.

Extraction technology: Single factor exploration

Genetics and Molecular Research 16 (1): gmr16019177 


\section{Extraction time}

The following conditions were used: weighted 5-g filter residues with a liquid-to-solid ratio of $25: 1$ and $\mathrm{pH} 10.0$ at $40^{\circ} \mathrm{C}$. The amount of extracted protein was measured at different times (Figure 2).

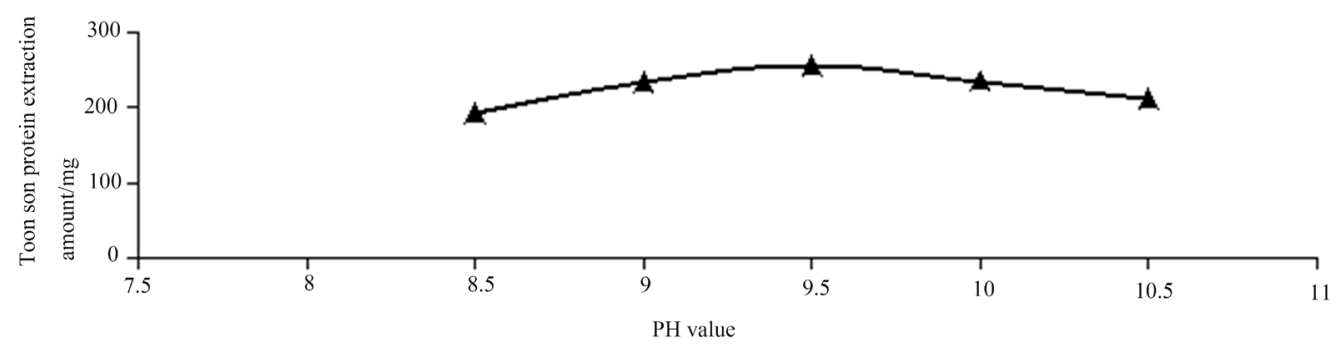

Figure 2. Effect of extraction $\mathrm{pH}$ on extraction amount.

\section{Extraction $\mathrm{pH}$}

Under the above conditions, the amount of extracted protein was measured at different pH levels (Figure 3).

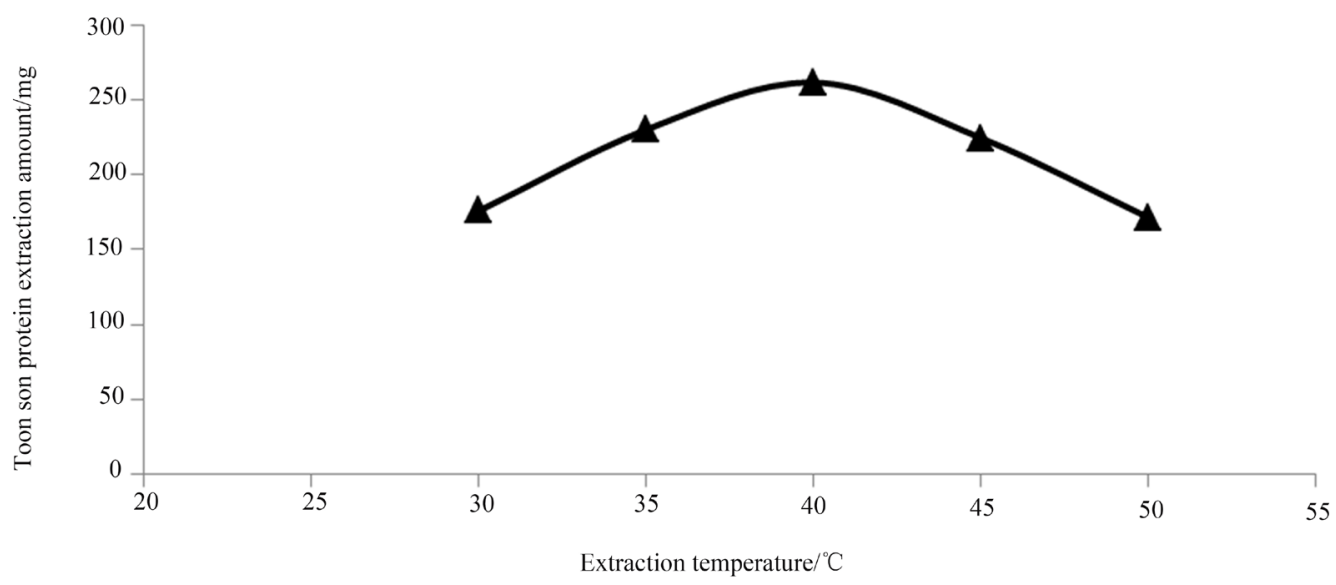

Figure 3. Effect of extraction temperature on extraction amount.

\section{Extraction temperature}

Using the conditions described above, the amount of extracted protein obtained at different temperatures was measured (Figure 4).

Genetics and Molecular Research 16 (1): gmr16019177 


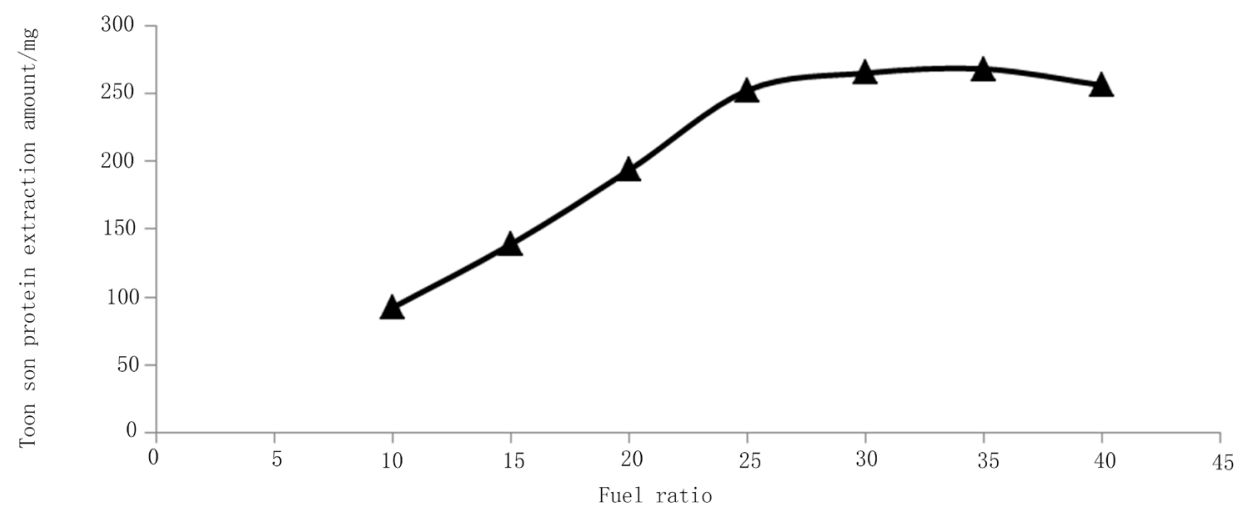

Figure 4. Effect of the liquid-to-solid ratio on extraction amount.

\section{Liquid-to-solid ratio}

Under the above conditions, the amount of extracted protein obtained under different liquid-to-solid ratios was measured (Figure 5).

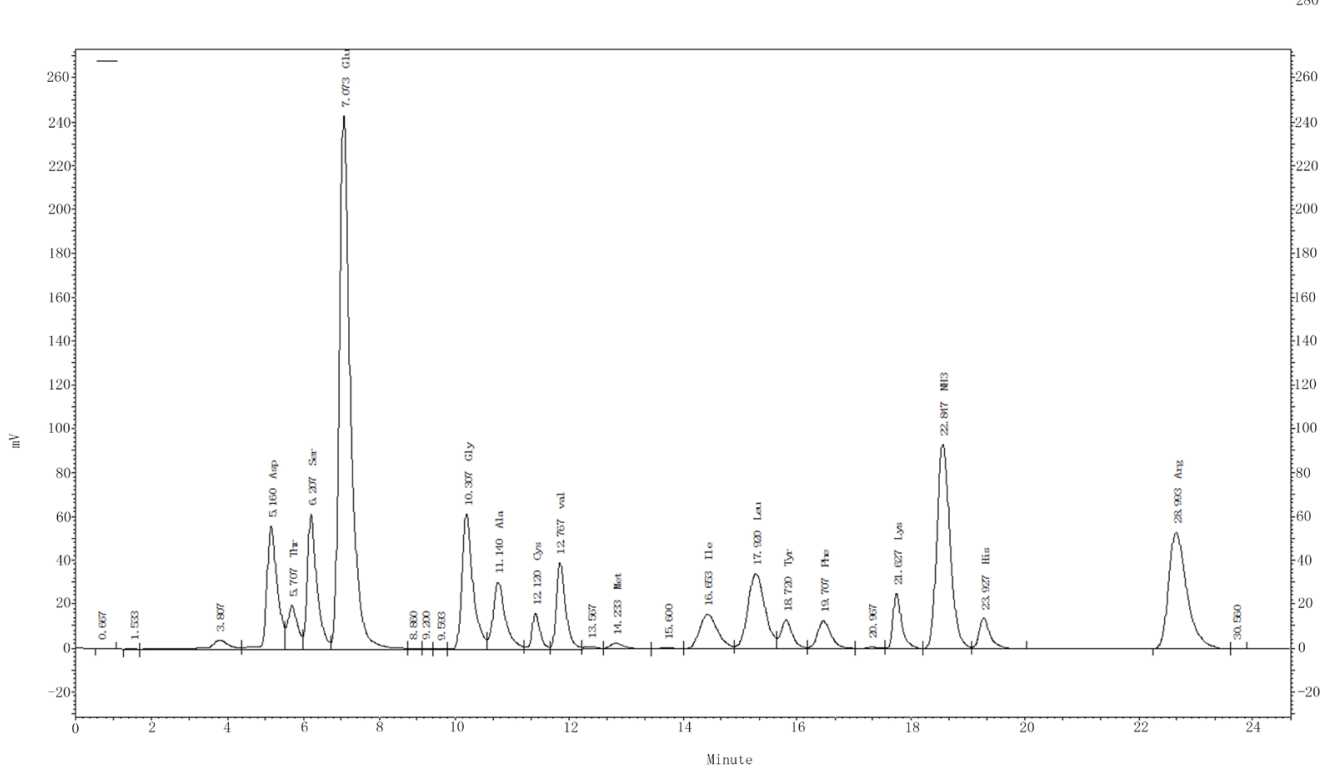

Figure 5. Chromatogram of hydrolyzed amino acid content in protein from Toona sinensis fruit.

\section{Orthogonal design}

The extraction time, $\mathrm{pH}$, temperature, and liquid-to-solid ratio were selected based on the results of the single factor exploration experiments. $\mathrm{An}_{9}\left(3^{4}\right)$ orthogonal table was used to confirm the extraction technology (Tables $1,2,3$ ).

Genetics and Molecular Research 16 (1): gmr16019177 
Table 1. Factor levels of extraction conditions for Toona sinensis proteins.

\begin{tabular}{l|c|c|c|c}
\hline \multirow{2}{*}{ Level } & $\mathrm{A}$ & $\mathrm{B}$ & $\mathrm{C}$ & D \\
\cline { 2 - 5 } & $\mathrm{pH}$ & Time & Liquid-to-solid ratio & Temperature \\
\hline 1 & 8.5 & 40 & $20: 1$ & 35 \\
\hline 2 & 9.5 & 45 & $25: 1$ & 40 \\
\hline 3 & 10.5 & 50 & $30: 1$ & 45 \\
\hline
\end{tabular}

Table 2. $\mathrm{L}_{9}\left(3^{4}\right)$ orthogonal test.

\begin{tabular}{|c|c|c|c|c|c|}
\hline No. & A & B & C & D & $\mathrm{mg}$ \\
\hline 1 & 1 & 1 & 1 & 1 & 193.7 \\
\hline 2 & 1 & 2 & 2 & 2 & 246.7 \\
\hline 3 & 1 & 3 & 3 & 3 & 227.6 \\
\hline 4 & 2 & 1 & 2 & 3 & 258.8 \\
\hline 5 & 2 & 2 & 3 & 1 & 207.7 \\
\hline 6 & 2 & 3 & 1 & 2 & 190.3 \\
\hline 7 & 3 & 1 & 3 & 2 & 237.8 \\
\hline 8 & 3 & 2 & 1 & 3 & 183.2 \\
\hline 9 & 3 & 3 & 2 & 1 & 253.0 \\
\hline K1 & 668 & 690.3 & 567.0 & 654.4 & \\
\hline $\mathrm{K} 2$ & 656.8 & 637.6 & 758.5 & 674.8 & \\
\hline K3 & 674 & 670.9 & 673.1 & 669.6 & \\
\hline $\mathrm{R}$ & 5.73 & 17.57 & 63.77 & 6.8 & \\
\hline
\end{tabular}

Table 3. Variance analysis.

\begin{tabular}{l|c|c|c|c}
\hline Factors & Sum of squares & $v$ & $\mathrm{~F}$ & $\mathrm{P}$ \\
\hline $\mathrm{pH}$ & 50.81 & 2 & 0.68 & 6.32 \\
\hline Time & 473.62 & 2 & 81.73 & $*$ \\
\hline Liquid-to-solid ratio & 6122.63 & 2 & 1 & \\
\hline Temperature & 74.92 & 2 & & \\
\hline Errors & 50.81 & 2 & & \\
\hline
\end{tabular}

$\mathrm{F}_{0.05}(1,2)=19$.

\section{Preliminary characterization of the physicochemical properties of T. sinensis fruit}

To determine the total nitrogen content in proteins from $T$. sinensis fruit, we weighed three 28-mg protein samples and measured the total nitrogen content according to Chinese Pharmacopoeia (2010, IX L) using the micro-Kjeldahl method.

The AA composition of $T$. sinensis fruit proteins was analyzed as follows: protein samples were pretreatment and $0.02816 \mathrm{~g}$ samples of each protein were placed in a tube for hydrolysis. To these, $6 \mathrm{~N} \mathrm{HCL}(15 \mathrm{~mL})$ was added and the samples was then vacuum degassed for $30 \mathrm{~min}$, nitrogenized, sealed, and placed in the dry oven at $110^{\circ} \mathrm{C}$ for hydrolysis for 22 h. After cooling, the digested samples were transferred into a 50-mL volumetric flask and made up to a constant volume with ultrapure water. Next, $2 \mathrm{~mL}$ of the digested sample was transferred to a 5-mL bottle and placed in a vacuum drying chamber at $50^{\circ} \mathrm{C}$. After drying, 1 $\mathrm{mL}$ ultrapure water was added and the samples were dried again. HCL $(1 \mathrm{~mL}, 0.02 \mathrm{~N})$ was added to dissolve the samples, which were then filtered through a $0.22-\mu \mathrm{m}$ film.

The following chromatography conditions were used: 2622 \# PHion exchange chromatograph $(4.5 \times 60 \mathrm{~mm})$; sample size $(20 \mu \mathrm{L})$; wavelengths of AAs were $570 \mathrm{~nm}$ except for proline $(440 \mathrm{~nm})$; the flow velocity of ninhydrin and loading buffer was 0.35 and 0.4 $\mathrm{mL} / \mathrm{min}$, respectively; the temperature of the derivative reactor was $57^{\circ} \mathrm{C}$; and the standard concentration of AA was $2 \mathrm{nmol} / 20 \mu \mathrm{L}$ with a single point correction (Table 4 and Figure 6).

Genetics and Molecular Research 16 (1): gmr16019177 
Table 4. Hydrolysis amino acid content in Toona sinensis fruit proteins.

\begin{tabular}{l|c|c|c}
\hline AA & Content (\%) & AA & Content (\%) \\
\hline ASP & 5.57 & ILE & 2.48 \\
\hline THR & 1.55 & LEU & 5.32 \\
\hline SER & 3.94 & TYR & 1.90 \\
\hline GLU & 27.05 & PHE & 1.94 \\
\hline GLY & 3.33 & LYS & 1.85 \\
\hline ALA & 2.25 & NH3 & 3.10 \\
\hline CYS & 1.52 & HIS & 1.49 \\
\hline VAL & 2.58 & ARG & 11.71 \\
\hline MET & 0.78 & PRO & 1.23 \\
\hline Sum $(\%)$ & & 76.48 & \\
\hline
\end{tabular}

A
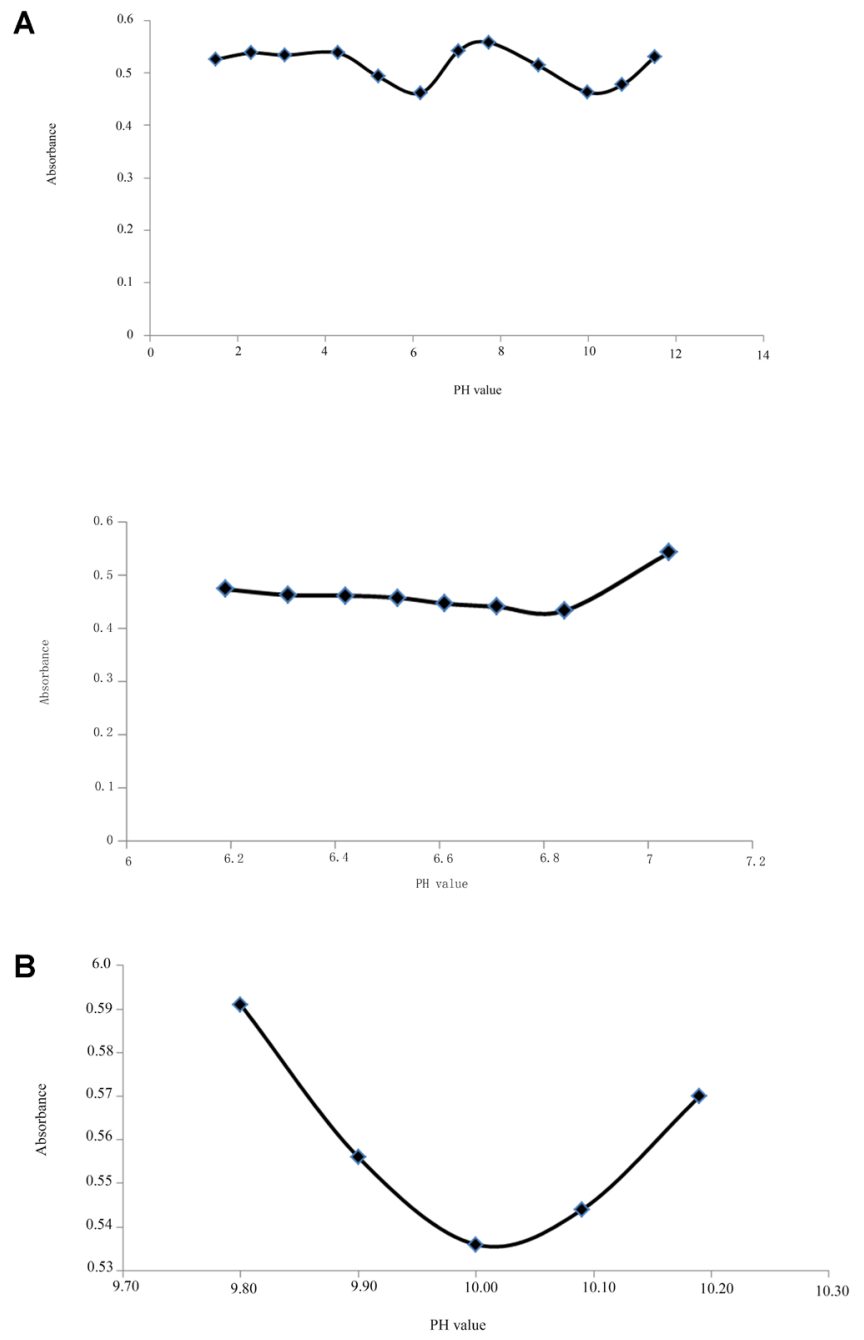

Figure 6. A Measuring the isoelectric point of proteins at $\mathrm{pH}$ 6-8 in Toona sinensis fruit.

Genetics and Molecular Research 16 (1): gmr16019177 
In addition, we detected the isoelectric point of the proteins in T. sinensis fruit.

The $\mathrm{pH}$ of the protein extracts was adjusted between 2 and 13 with 12 points in total using $0.2 \mathrm{M} \mathrm{NaOH}$ and $0.2 \mathrm{M} \mathrm{HCl}$ (Huang et al., 2008). The $\mathrm{pH}$ values used to obtain minimum and the maximum measurable absorbance were explored and eight points around the maximum were set with spacings of 0.4 to confirm the isoelectric point.

The infrared spectrum was used to analyze the proteins in $T$. sinensis fruit. Polysaccharide samples were mixed with dried $\mathrm{KBr}$ powder, fully ground, and scanned at the wave band of $4000-400 \mathrm{~cm}^{-1}$.

SDS-PAGE was used to determine the molecular weight of the proteins in T. sinensis fruit. According to Laemmli (Hamisi and Likewude, 1994), the SDS-PAGE conditions included $5 \%$ stacking gel, $12 \%$ separation gel, and $200-\mathrm{mA}$ current for $2.5 \mathrm{~h}$.

\section{RESULTS}

\section{BSA standard curve}

The absorbance increased as the BSA concentration increasing from 0 to $0.9 \mathrm{mg} / \mathrm{mL}$, which presented a linear relationship. The equation was as follows: $\mathrm{y}=7.7931 \mathrm{x}+0.0152, \mathrm{r}$ $=0.9994$.

\section{Extraction technology: Single factor exploration}

\section{Extraction time}

As shown in Figure 1, the protein content increased as the extraction time increased within the range 0-45 min. After $45 \mathrm{~min}$, the protein content tended to be stable. Thus, the optimal extraction time was determined to be $45 \mathrm{~min}$.

\section{Extraction pH}

The results showed that the protein content increased with $\mathrm{pH}$ from 8.5 to 9.5. When the $\mathrm{pH}$ exceeded 9.5, the protein content decreased gradually. The reason for this might be the increased negative charges of the protein in alkaline solution, which influence the interactions between protein and solution, and protein and protein, and hence, the solubility (Figure 2).

\section{Extraction temperature}

The results showed that the protein content increased as the temperature increased from 0 to $40^{\circ} \mathrm{C}$. When the temperature exceeded $40^{\circ} \mathrm{C}$, the protein content decreased gradually. Thus, the optimal extraction temperature was $40^{\circ} \mathrm{C}$ as shown in Figure 3.

\section{Liquid-to-solid ratio}

As shown in Figure 4, the protein content increased as the liquid-to-solid ratio increased. The maximum protein content was obtained when the liquid-to-solid ratio was 25:1. Combining the extraction amount and the costs, the optimal liquid-to-solid ratio was 25:1.

Genetics and Molecular Research 16 (1): gmr16019177 


\section{Orthogonal test}

As shown in Tables 1, 2, and 3, using the T. sinensis fruit protein as the index, the liquid-to-solid ratio had the most influence followed by the extraction time, temperature, and $\mathrm{pH}(\mathrm{C}>\mathrm{B}>\mathrm{D}>\mathrm{A})$. The optimal condition was $\mathrm{A}_{3} \mathrm{~B}_{1} \mathrm{C}_{2} \mathrm{D}_{2},\left(\mathrm{pH} 10.5,40 \mathrm{~min}, 40^{\circ} \mathrm{C}\right.$, liquid:solid $=25: 1)$.

\section{Verification of technology}

Using the optimal condition of $\mathrm{A}_{3} \mathrm{~B}_{1} \mathrm{C}_{2} \mathrm{D}_{2}$, three samples of proteins from $T$. sinensis fruit were selected. Their weights were $255.9,260.5$, and $264.7 \mathrm{mg}$, with an average of 260.4 $\mathrm{mg}$, standard deviation (S) of 4.40, relative standard deviation (RSD) of $1.69 \%(\mathrm{~N}=3)$, which indicated the stability of the $\mathrm{A}_{3} \mathrm{~B}_{1} \mathrm{C}_{2} \mathrm{D}_{2}$ technology.

\section{Preliminary characterization of the physicochemical properties of T. sinensis fruit proteins}

The automatic Kieltec Distilling system azotometer was used to measure total nitrogen content in T. sinensis fruit protein, and their total nitrogen content was $13.8 \mathrm{~g} / 100 \mathrm{~g}, 13.9$ $\mathrm{g} / 100 \mathrm{~g}$, and $13.7 \mathrm{~g} / 100 \mathrm{~g}$, with an average of $13.8 \mathrm{~g} / 100 \mathrm{~g}$.

According to GB/T18246-2000 analysis, the AA composition of $T$. sinensis fruit proteins is shown in Table 4 and Figure 5. There were 17 different AAs in T. sinensis fruit proteins. The glutamate level was the highest at $35.37 \%$, followed by arginine at $15.31 \%$, and methionine was the lowest at $1.02 \%$.

The isoelectric points of proteins in T. sinensis fruit were measured and are shown in Figure $6 \mathrm{~A}$ and $\mathrm{B}$. The results revealed that there were two clear wave crests between $\mathrm{pH} 1.0$ and 11.0 when the protein content was measured by Coomassie brilliant blue staining, which indicated that there were two different proteins with different isoelectric points, and their $\mathrm{pH}$ values were 6.0 and 10.0, respectively. The absorbance of the supernatant was low, indicating that the quantity of precipitate was high at this $\mathrm{pH}$. Figure $6 \mathrm{~B}$ shows that the absorbance was lowest, and the precipitation was highest, at $\mathrm{pH} 10.0$, which indicated that $\mathrm{pH} 10.0$ was an isoelectric point.

Next, the infrared spectrum was used to analyze the proteins in $T$. sinensis fruit. The strong and wide absorption peak at $3395.79 \mathrm{~cm}^{-1}$ represented the stretching vibration of the $\mathrm{N}-\mathrm{H}$ bond; $2933.19 \mathrm{~cm}^{-1}$ was fermi resonance; $1655.68 \mathrm{~cm}^{-1}$ was the stretching vibration of the $\mathrm{C}=0$ bond; $1536.10 \mathrm{~cm}^{-1}$ was the bending and stretching vibration of the N-H and $\mathrm{C}-\mathrm{N}$ bonds; $1322.25,1281.50$, and $1238.61 \mathrm{~cm}^{-1}$ were the bending vibrations of $\mathrm{C}-\mathrm{N}$ and $\mathrm{N}-\mathrm{H} ; 594.82 \mathrm{~cm}^{-1}$ was the out of plane of $\mathrm{C}=0$ bending vibration. The results are shown in Figure 7.

In addition, we also analyzed the molecular weights of the proteins from $T$. sinensis fruit. The proteins were mainly concentrated between 66.2 and $18.4 \mathrm{kDa}$, including three bands at 66.2-45.0 and 25.0-18.4 kDa, which were 55, 51, and $22 \mathrm{kDa}$, respectively, as shown in Figure 8.

Genetics and Molecular Research 16 (1): gmr16019177 


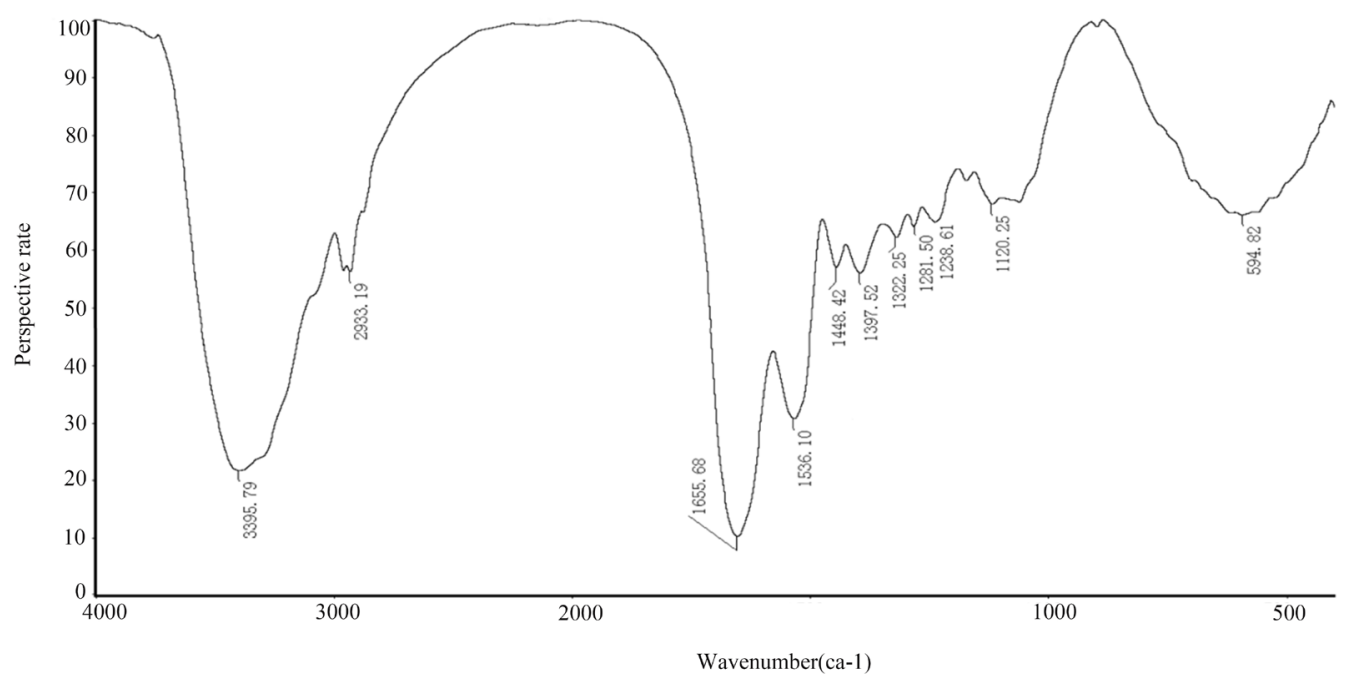

Figure 7. B Measuring the isoelectric point of proteins at pH 9-10 in Toona sinensis fruit.

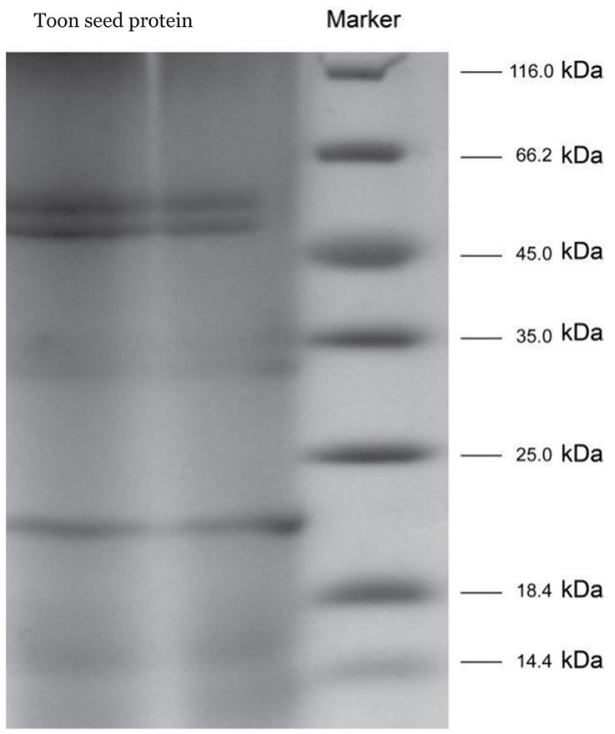

Figure 8. Infrared spectrum analyzing the proteins in Toona sinensis fruit.

\section{DISCUSSION}

As a component of traditional Chinese medicine, T. sinensis fruit has many medical effects, due to the presence of many active compounds, including phenols, tannins, alkaloids, saponins, steroids, terpenes, and volatile oil.

Although there have been some studies on its effects, few studies on T. sinensis fruit proteins, and the extraction technology used for health products, foods, and medicines was 
under the exploring stage in these fields. This study was performed to investigate the extraction of $T$. sinensis fruit proteins, and to preliminarily characterize the physicochemical properties of the proteins.

In our study, we optimized the extraction technology of proteins in T. sinensis fruit. The results showed that the optimal $\mathrm{pH}$ was 10.5 , extraction time was $40 \mathrm{~min}$, liquid-to-solid ratio was $25: 1$, and the temperature was $40^{\circ} \mathrm{C}$. Under these optimal conditions, the concentration of extracted protein was $260.4 \mathrm{mg}$. The total nitrogen content in $T$. sinensis fruit proteins was $13.8 \mathrm{~g} / 100 \mathrm{~g}$, and included 17 different AAs. The content of Glu and Arg was 50.68\% of the total, which indicated that this protein has potential uses as well as developmental prospects. The isoelectric point of $T$. sinensis fruit proteins was between 6.8 and 10.0. The results of SDSPAGE revealed three protein bands at 55, 51, and $22 \mathrm{kDa}$. Our investigation of the proteins of T. sinensis fruit provided the evidence and references for further researches.

\section{Conflicts of interest}

The authors declare no conflict of interest.

\section{ACKNOWLEDGMENTS}

Supported by the National Natural Science Foundation of China (Grand \#81274049).

\section{REFERENCES}

Appel LJ (2003). The effects of protein intake on blood pressure and cardiovascular disease. Curr. Opin. Lipidol. 14: 5559. http://dx.doi.org/10.1097/00041433-200302000-00010

Chen TS, Luo ZP, Cui HA, et al. (2000). Preliminary study of chemical constituents from leaves of Toona sinensis. Shanxi For. Sci. Technol. 20: 1-2.

Chen YL, Yuan ZP and Li CL (2008). Studies on chemical constituents and pharmacological effects toon. J. Changzhi Medical College. 22: 315-317.

He ZY and Lin L (2013). Toon chemical constituents and pharmacological research progress. Gansu Zhongyi Xueyuan Xuebao 30: 64-66.

Higashi K, Abata S, Iwamoto N, Ogura M, et al. (2001). Effects of soy protein on levels of remnant-like particles cholesterol and vitamin E in healthy men. J. Nutr. Sci. Vitaminol. 47: 283-288. http://dx.doi.org/10.3177/jnsv.47.283

Huang J, Xiong H, Liang LI, et al. (2008). Enzymolysis of residue of rice and determination of its protein isoelectric point. Sci. Technol. Food Ind. 37: 174-176.

Hamisi BD and Likewude D (1994). Gel electrophoresis of proteins: a practical approach[M] Beijing Science Press 19221.

Jenkins DJ, Kendall CW, Vidgen E, Augustin LS, et al. (2001). High-protein diets in hyperlipidemia: effect of wheat gluten on serum lipids, uric acid, and renal function. Am. J. Clin. Nutr. 74: 57-63.

Lee YS and Jung EH (2002). Dietary Soy Protein and Calcium Reduce Serum Lipid and Cholesterol in Rats Fed Fat Enriched Diets. J. Food Sci. Nutr. 7: 367-372.

Rowlands JC, He L, Hakkak R, Ronis MJ, et al. (2001). Soy and whey proteins downregulate DMBA-induced liver and mammary gland CYP1 expression in female rats. J. Nutr. 131: 3281-3287.

Tang ZT, Jin XH, Xie JL, Bo JB, et al. (1996). Study on protein energy malnutrition cirrhosis after hepatitis. Chin. J. Dig. 16: 346-348

Wang ML, Tu BK and He D (2006). Chemical constituents of Toon progress. Hubei For. Sci. Technol. 140: 38-40.

Wang WP, Guo SY, Li L, Wang ML, et al. (2008). Coomassie brilliant blue method for the determination of protein polysaccharides. Food Res. Dev. 29: 1150-117.

Xing SS and Chen C (2010). Advances in Chemical Constituents and Toon Journal of Anhui Agricultural Sciences 38: 8978-8979.

Genetics and Molecular Research 16 (1): gmr16019177 